\title{
Detection of aerobic bacterial pathogens associated with early embryonic death in pregnant New Zealand female Rabbits in Egypt
}

\author{
Heba Roshdy (iD, Azhar G. Shalaby (D), Ahmed Abd Elhalem Mohamed (D) and Heba Badr(D) \\ Reference Laboratory for Veterinary Quality Control on Poultry Production, Animal Health Research Institute, Agricultural \\ Research Center, Nadi El-Seid Street, Dokki P.O. Box246, Giza 12618, Egypt. \\ Corresponding author: Heba Badr, e-mail: drheba_badr@yahoo.com \\ Co-authors: HR: roshdy2019@yahoo.com, AGS: azhar_gaber@yahoo.com, AAEM: vet_t2050@yahoo.com \\ Received: 23-11-2020, Accepted: 08-03-2021, Published online: 24-04-2021
}

doi: www.doi.org/10.14202/vetworld.2021.986-995 How to cite this article: Roshdy $H$, Shalaby AG, Mohamed AAE, Badr H (2021) Detection of aerobic bacterial pathogens associated with early embryonic death in pregnant New Zealand female Rabbits in Egypt, Veterinary World, 14(4): 986-995.

\begin{abstract}
Background and Aim: Rabbits are a highly sensitive species and susceptible to various bacterial pathogens that may be causative agents for early embryonic death. This study aimed to explore the administration of different bacterial agents in does suffering from early embryonic death. Furthermore, identification of genes associated with virulence was performed to identify the phenotypic and genotypic antimicrobial resistance patterns that may increase the virulence of pathogens and lead to early embryonic death.

Materials and Methods: We isolated and identified bacterial agents in 106 samples from live and dead female rabbits that had undergone early embryonic death, including liver and intestine tissue, aborted fetuses, discharges, and vaginal swabs. Conventional polymerase chain reaction (PCR) was conducted to confirm the identity of the isolated bacterial strains and their virulence. Moreover, antibiotic resistance was studied phenotypically and genotypically.

Results: We isolated Escherichia coli, Salmonella, Staphylococcus aureus, Pasteurella multocida, and Listeria monocytogenes. PCR confirmed typical identification except in P. multocida, which was confirmed as Gallibacterium spp. in some cases. The final percentage of detection was $34 \%, 30.2 \%, 16.9 \%, 13.2 \%$, and $11.3 \%$, respectively. Virulence properties were investigated using different designated genes. All Salmonella strains harbored invA, stn, avrA, and ompf genes, while the $s o p E$ gene was identified in $31.25 \%$. E. coli strains harboring the iss gene lacked the shiga toxin (stxl) gene. L. monocytogenes and S. aureus strains harbored the hemolysin gene (66.7\% and 33.4\%, respectively). Multidrug resistance was detected phenotypically and genotypically in most strains. Each bacterial pathogen had a different antibiotic resistance profile.
\end{abstract}

Conclusion: Multiple bacterial species may contribute to early embryonic death in does. Furthermore, the combined infection could be the main cause of early embryonic death. Thus, monitoring programs should bear this in mind and focus on the early detection of these bacterial agents in female rabbits to avoid embryonic death.

Keywords: early embryonic death, Escherichia coli, Listeria, Rabbits, Salmonella, Staphylococcus aureus.

\section{Introduction}

Rabbit meat is a source of protein of animal origin and has a high yield [1]. However, rabbits are highly susceptible to various bacterial infections that can be harmful to their health [2]. Early embryonic death refers to the expulsion of a living or dead fetus from the uterus before completing gestation and is usually caused by agents affecting the fetus, its membranes, or both. There are many reasons for fetal death and early embryonic deaths in rabbits, including nutrient deficiency, bacteria, viruses, mycotic and protozoal organisms, toxic agents, and endocrine disorders [3]. Escherichia coli is part of the normal microflora colonizing the gastrointestinal tract of rabbits, and certain

Copyright: Roshdy, et al. Open Access. This article is distributed under the terms of the Creative Commons Attribution 4.0 International License (http://creativecommons.org/licenses/ by/4.0/), which permits unrestricted use, distribution, and reproduction in any medium, provided you give appropriate credit to the original author(s) and the source, provide a link to the Creative Commons license, and indicate if changes were made. The Creative Commons Public Domain Dedication waiver (http:// creativecommons.org/publicdomain/zero/1.0/) applies to the data made available in this article, unless otherwise stated. strains have been associated with intestinal or extra-intestinal infections. Colibacillosis, a common disease in rabbits, is one of the major infectious diseases that endanger the rabbit breeding industry [4]. Virulence factors related to the pathogenicity of extra-intestinal infections of $E$. coli are numerous and have a wide range of activities, from those related to bacteria colonization to those related to virulence, including adhesions, toxins, and iron acquisition factors [5].

Salmonella spp. infection in rabbits is characterized by diarrhea, septicemia, and rapid death, and pregnant does commonly abort [6]. Staphylococcus aureus is one of the common pathogens causing inflammation in the uterus and abscess or dermatitis in rabbits that are a cause of mortality in young and newly-born rabbits [7]. Does that test positive Pasteurella multocida, especially from nasal discharge, often is positive for P. multocida from vaginal discharge [6], with commonly observed clinical signs, such as discharge from urogenital opening. Other signs include depression and inappetence with severe emaciation and variable mortality rates [8]. 
Listeria monocytogenes is transmitted by ingestion or inhalation. The infection causes septicemia in young rabbits; meningoencephalitis in adults; and metritis, spontaneous abortion, fetal or neonatal death, and fetal mortality in pregnant does [6]. Antimicrobials drugs are used as preventive measures, as prophylactic treatment during outbreaks of infectious bacterial diseases, and as growth promoters [9]. However, defective policies induce resistance in most pathogens, even in the commensal bacterial of individuals or groups [10].

The significance of this study is its focus on identifying bacterial pathogens that cause early embryonic death in does. This study aimed to explore the administration of different bacterial agents in does suffering from early embryonic death. Furthermore, identification of genes associated with virulence was performed to identify the phenotypic and genotypic antimicrobial resistance patterns that may increase the virulence of pathogens and lead to early embryonic death.

\section{Materials and Methods}

\section{Ethical approval}

Handling of rabbits during sample collection was in accordance with the regulations for the care and welfare of examined animals and approved by the Animal Care Committee of the Animal Health Research Institute.

\section{Study period and location}

The samples collected from January 2018 to August 2019. The sensitivity, serotyping, and PCR were conducted till May 2020 at Reference Laboratory for Veterinary Quality Control on Poultry Production.

\section{Sample collection}

We collected 106 samples from New Zealand female rabbits (does) with aborted fetuses as follows: 20 vaginal swabs from live rabbits who had aborted fetuses, 60 samples from freshly dead does (20 uterine secretions, 24 liver samples, and 16 intestine samples), and 26 dead fetuses aborted by the does Table1. Samples were collected from animals presented to the Reference Laboratory for Veterinary Quality Control on Poultry Production laboratory under aseptic conditions.

\section{Bacterial isolation}

Samples were examined bacteriologically to identify the different bacterial species that may have caused the cases of abortion, such as E. coli, Salmonella,

Table-1: Type of examined samples.

\begin{tabular}{llc}
\hline Sample & Organs & $\begin{array}{c}\text { No. of examined } \\
\text { samples }\end{array}$ \\
\hline Live disease does & Vaginal swabs & 20 \\
Freshly dead does & Uterine secretions & 20 \\
& Liver & 24 \\
Aborted fetus & Intestine & 16 \\
Total & Fetus & 26 \\
\hline
\end{tabular}

S. aureus, Pasteurella spp., and L. monocytogenes.

\section{Isolation and identification of E. coli}

$E$. coli was isolated and identified according to Lee and Nolan [11]. Briefly, all the collected samples were pre-enriched in buffered peptone water (Oxoid, UK) and incubated aerobically at $37^{\circ} \mathrm{C}$ for $24 \mathrm{~h}$. Then, a loopful of the broth culture was inoculated onto MacConkey agar (Neogen, US) and eosin methylene blue agar (LabM, UK) plates and reincubated at $37^{\circ} \mathrm{C}$ for $24 \mathrm{~h}$. The isolated colonies were identified morphologically and biochemically (oxidase strips and triple sugar iron agar from Oxoid; urea, Simmon citrate agar, and peptone water from LabM; and Kovac reagent from HiMedia, India).

\section{Serotyping of E. coli isolates}

Slide agglutination was used for serotyping the E. coli isolates according to their somatic $(\mathrm{O})$ antigens using an E.coli antiserum kit (Denka Seiken Co., Ltd, Japan). First, the fresh culture was mixed with normal saline as a control (negative agglutination). Then, the culture was tested with polyvalent $O$ groups 1-8 and if positive, with the monovalent antisera included in the positive polyvalent group.

\section{Isolation and identification of Salmonella spp.}

Salmonella spp. were isolated and identified, according to ISO 6579-1 [12]. Briefly, the samples were pre-enriched in buffered peptone water (Oxoid) and incubated at $37^{\circ} \mathrm{C}$ for $16-18 \mathrm{~h}$. Then, $0.1 \mathrm{~mL}$ of the incubated pre-enrichment medium was transferred to modified semisolid Rappaport-Vassiliadis medium (Oxoid) and incubated at $41.5^{\circ} \mathrm{C}$ for $24 \mathrm{~h}$. Furthermore, $1 \mathrm{~mL}$ of the incubated pre-enrichment medium was transferred to Muller-Kauffmann tetrathionate-novobiocin broth (Oxoid), which was incubated aerobically at $37^{\circ} \mathrm{C}$ for $24 \mathrm{~h}$. Following incubation, the cultures were onto xylose lysine deoxycholate (Oxoid) and Hektoen enteric agar (Liofilchem, Italy) agar plates and incubated aerobically at $37^{\circ} \mathrm{C}$ for $24 \mathrm{~h}$. The typical colonies were selected and identified by biochemical tests using urea agar, triple sugar iron agar, and lysine iron agar (Liofilchem).

\section{Serotyping of isolated Salmonella species}

We performed serotyping of the isolated Salmonella species according to ISO 6579-3 [13] using the slide agglutination method with Salmonella antiserum (Sifin Co., Germany). First, the fresh culture was mixed with normal saline as a control (negative agglutination). Then, the culture was tested with polyvalent $\mathrm{O}$ groups followed by polyvalent flagellar $(\mathrm{H})$ groups, and if positive, with the monovalent $\mathrm{O}$ and $\mathrm{H}$ antisera to determine the serotype of the Salmonella strains according to the Kauffman-White classification [14].

\section{Isolation and identification of S. aureus}

The isolation and identification of $S$. aureus were performed according to standard methods $[15,16]$. 
Inoculated pre-enriched buffer was plated on Baird Parker agar (Oxoid) and incubated at $37^{\circ} \mathrm{C}$ for 24-48 h. The isolated colonies were identified morphologically (black colony surrounded with double zones indicating tellurite reduction with lipase activity), microscopically (Gram-positive grape-like structure), and biochemically (positive for the slide catalase test, mannitol fermentation, tube coagulase test, and acetoin production [Voges-Proskauer test] and oxidase-negative).

\section{Isolation and Identification of Pasteurella spp.}

Isolation and identification of Pasteurella spp. were performed as per Glisson et al. [17]. Briefly, a loopful of each sample was inoculated under aseptic conditions on $7 \%$ sheep blood agar plates (LabM) and incubated for $24 \mathrm{~h}$ at $37^{\circ} \mathrm{C}$. Dew drop-like mucoid non-hemolytic colonies were subjected for further biochemical identification oxidase and indole positive and microscopy showing Gram-negative coccobacilli with characteristic staining bipolarity[17]. MacConkey agar media were used to differentiate $P$. multocida from other members of the Pasteurellaceae family.

\section{Isolation and identification of L. monocytogenes}

L. monocytogenes was isolated and identified, according to ISO 11290-1 [18]. Briefly, the samples were inoculated into a selective primary enrichment medium (half Fraser broth, Oxoid) and incubated at $30^{\circ} \mathrm{C}$ for $24 \mathrm{~h}$, followed by inoculation of $0.1 \mathrm{~mL}$ of the incubated broth into a full-strength secondary liquid enrichment medium (full Fraser broth, Oxoid). After incubation at $37^{\circ} \mathrm{C}$ for $24 \mathrm{~h}$, the broth was streaked on Agar Listeria according to Ottaviani and Agosti (ALOA) medium and Oxford agar (LabM and Oxoid) and incubated at $37^{\circ} \mathrm{C}$ for $24-48 \mathrm{~h}$. The typical colonies were blue-green surrounded with or without an opaque halo on ALOA agar and olive green with a black halo on Oxford agar. Then, the Listeria strains were identified using API strips (BioMérieux, France).

\section{Antimicrobial sensitivity test}

The antibiograms of all isolates were performed by the disk-diffusion method [19] against 11 antibiotics (Oxoid), namely, ampicillin (AMP10), cefotaxime (CTX30), ceftriaxone (CRO30), chloramphenicol (C30), ciprofloxacin (CIP5), doxycycline (DO30), gentamycin (CN10), norfloxacin (NOR10), streptomycin (S10), tetracycline (T30), and trimethoprim-sulfamethoxazole (SXT25), and interpreted, according to the Clinical and Laboratory Standards Institute guidelines [20].

\section{Molecular assessment}

DNA was extracted from culture broth using a QIAamp DNA Mini Kit (Qiagen, Germany, GmbH Catalogue no.51304). The extracted DNA was used in subsequent polymerase chain reaction (PCR) assays for species confirmation and to detect genes responsible for virulence and antimicrobial agent resistance PCR was performed in a final volume of $25 \mu \mathrm{L}$ that contained $12.5 \mu \mathrm{L}$ of EmeraldAmp MAX PCR Master Mix (Emerlad, Amp GT (2× premix), Japan), $1 \mu \mathrm{L}$ of each primer at concentrations of $20 \mathrm{pmol}, 4.5 \mu \mathrm{L}$ of diethylpyrocarbonate water, and $6 \mu \mathrm{L}$ of the DNA template. The reaction was performed in a Biometra thermal cycler, T3000 (Germany). The oligonucleotide primers (Table-2) [21-38] were supplied by Metabion, Germany.

The PCR products were separated by electrophoresis according to Sambrook et al. [39] on a 1\% agarose gel (Applichem, Germany, $\mathrm{GmbH}$ ) in $1 \times$ TBE buffer at room temperature using a gradient of $5 \mathrm{~V} / \mathrm{cm}$. Each well was loaded with $15 \mu \mathrm{L}$ of the PCR product. A Gelpilot 100 bp (Qiagen) ladder was used to determine the fragment sizes. The gel was photographed by a gel documentation system (Biometra BDA digital, Germany), and the data were analyzed using gel documentation system (Alpha Innotech, Biometra Germany) and the computer software (automatic image capture software protein simple formerly Cell Bioscience, USA).

\section{Results}

\section{Bacteriological results}

The 106 samples of female rabbits suffering from early embryonic death were examined for E. coli, Salmonella, S. aureus, Pasteurellaceae, and Listeria isolation, and mixed infections were recognized. E. coli, Salmonella spp., S. aureus, Pasteurella spp., and Listeria spp. were identified in $36(34 \%), 32$ (30.2\%), $18(16.9 \%), 14(13.2 \%)$, and $12(11.3 \%)$ samples, respectively (Table-3). Different serotypes of $E$. coli were detected (O125, O111, O114, O142, O167, O152, and O119). Different Salmonella serotypes were also identified; most serovars were $S$. Enteritidis, followed by $S$. Typhimurium, $S$. Give, $S$. Stuttgart, and then $S$. London, $S$. Derby, $S$. Elisabethville, and $S$. Suberu (Table-4).

The PCR results confirmed 18 (16.9\%) isolates as $S$. aureus using the clfA gene. In addition, although 14 Pasteurella spp. were identified as P. multocida by morphologic, microscopic, and biochemical characteristics, confirmation by PCR assay using three different genes identified 12 of the 14 strains as Gallibacterium spp (Gallibacterium is a genus of Pasteurellaceae family).

Regarding the confirmation of characterized colonies on ALOA agar by API, four typical isolates were identified as L. monocytogenes (identified no. 6510) and confirmed by PCR using $16 S R N A$ for $L$. monocytogenes, and the remaining eight isolates were identified as Listeria grayi (identified no. 3520).

\section{Antimicrobial results}

The results of antimicrobial sensitivity testing all isolates of E. coli, Salmonella, S. aureus, Pasteurella spp., and Listeria spp. are shown in Table-5. The E. coli isolates were highly resistant to tetracycline $(94.4 \%)$ and doxycycline $(88.9 \%)$. They were also resistant to trimethoprim-sulfamethoxazole $(55.6 \%)$; norfloxacin, 
Table-2: Primers sequences, target genes, amplicon sizes, and cycling conditions.

\begin{tabular}{|c|c|c|c|c|c|}
\hline Organism & Target genes & Primers sequences & Amplified & Annealing & Reference \\
\hline \multirow[t]{14}{*}{ Escherichia coli } & phoA & CGATTCTGGAAATGGCAAAAG & 720 & 58 & {$[21]$} \\
\hline & & CGTGATCAGCGGTGACTATGAC & & & \\
\hline & Iss & ATGTTATTITCTGCCGCTCTG & 266 & 54 & [22] \\
\hline & & CTATTGTGAGCAATATACCC & & & \\
\hline & $s t \times 1$ & ACACTGGATGATCTCAGTGG & 614 & 58 & {$[23]$} \\
\hline & & CTGAATCCСССТССАTTATG & & & \\
\hline & tet $(\mathrm{A})$ & GGTTCACTCGAACGACGTCA & 576 & 50 & {$[24]$} \\
\hline & & CTGTCCGACAAGTTGCATGA & & & \\
\hline & bla TEM & ATCAGCAATAAACCAGC & 516 & 54 & {$[25]$} \\
\hline & & CCCCGAAGAACGTTITC & & & \\
\hline & qnrS & CTATTGTGAGCAATATACCC & 516 & 55 & {$[26]$} \\
\hline & & TAAATTGGCACCCTGTAGGC & & & \\
\hline & aad1 & TATCAGAGGTAGTTGGCGTCAT & 484 & 54 & {$[24]$} \\
\hline & & GTTCCATAGCGTTAAGGTTTCATT & & & \\
\hline \multirow[t]{12}{*}{ Salmonella } & invA & GTGAAATTATCGCCACGTTCGGGCAA & 284 & 55 & {$[27]$} \\
\hline & & TCATCGCACCGTCAAAGGAACC & & & \\
\hline & stn & TTG TGT CGC TAT CAC TGG CAA CC & 617 & 59 & {$[28]$} \\
\hline & & ATT CGT AAC CCG CTC TCG TCC & & & \\
\hline & avrA & CCT GTA TTG TTG AGC GTC GTC TGG & 422 & 58 & [29] \\
\hline & & AGA AGA GCT TCG TTG AAT GTC C & & & \\
\hline & sopE & ACT CCT TGCACA ACC AAA & 422 & 58 & \\
\hline & & TGC GGA TGT CTT CTG CAT TTC GCC ACC & & & \\
\hline & $o m p F$ & CCTGGCAGCGGTGATCC & 519 & 50 & [30] \\
\hline & & TGGTGTAACCTACGCCATC & & & \\
\hline & qac ED1 & TAA GCC CTA CACAAA TTG GGA GAT AT & 362 & 58 & [31] \\
\hline & & GCC TCC GCA GCG ACT TCCACG & & & \\
\hline \multirow[t]{4}{*}{ Staphylococcus aureus } & clfA & GCAAAATCCAGCACAACAGGAAACGA & 638 & 55 & [32] \\
\hline & & CTTGATCTCCAGCCATAATTGGTGG & & & \\
\hline & $h / g$ & GAAGTCTGGTGAAAACCCTGA & 704 & 60 & [33] \\
\hline & & TGAATCCTGTCGCTAATGCC & & & \\
\hline Family & *Kmt1 & ATC-CGC-TAT-TTA-CCC-AGT-GG & 460 & 55 & [34] \\
\hline \multirow[t]{5}{*}{ Pasteurellacae } & & GCT-GTA-AAC-GAA-CTC-GCC-AC & & & \\
\hline & *ssa & ТТСАСАТСТТСАТССТС & 506 & 45 & {$[35]$} \\
\hline & & TाTTCATCCTCTTCGTC & & & \\
\hline & *16S rRNA-23S & STATTCTTTGTTACCARCGG & 1032 & 55 & [36] \\
\hline & rRNA & GGTTTCCCCATTCGG & & & \\
\hline \multirow[t]{3}{*}{ Listeria monocytogens } & $16 S$ RNA & $\begin{array}{l}\text { ggA CCg ggg CTA ATA CCg AAT gAT AA } \\
\text { TTC ATg TAg gCg AgT TgC AgC CTA }\end{array}$ & 1200 & 60 & [37] \\
\hline & hlyA & GCA-TCT-GCA-TTC-AAT-AAA-GA & 174 & 50 & {$[38]$} \\
\hline & & TGT-CAC-TGC-ATC-TCC-GTG-GT & & & \\
\hline
\end{tabular}

*Kmt1 (P.multocida), *ssa (Mannheimia) and *16S rRNA-23S rRNA (Gallibacteria)

Table-3: Incidence of pathogenic microorganisms isolated from live and freshly dead pregnant female rabbit and its aborted fetus.

\begin{tabular}{lccccc}
\hline Samples & \multicolumn{4}{c}{ No. of isolated microorganisms } \\
\cline { 2 - 5 } & Escherichia coli & Salmonella & S. aureus & Pasteurellacae & Listeria \\
\hline Vaginal swabs (diseased does) & 8 & 8 & 2 & 0 & 4 \\
Uterine secretions (dead does) & 4 & 8 & 8 & 2 & 4 \\
Liver & 14 & 6 & 2 & 0 & 0 \\
Intestine & 4 & 2 & 6 & 8 & 0 \\
Aborted fetus & 6 & 8 & 18 & 14 & 12 \\
Total & 36 & 32 & $16.90 \%$ & $13.20 \%$ & $11.30 \%$ \\
\% from total -examined (106) & $34 \%$ & $30.20 \%$ & & & 0 \\
\hline
\end{tabular}

ciprofloxacin, and streptomycin (66.7\%); and ampicillin and chloramphenicol (50\%). On the other hand, Salmonella only showed a high resistance for streptomycin $(68.7 \%)$. Isolates of $S$.aureus showed complete resistance to gentamicin $(100 \%)$, followed by ampicillin $(88.9 \%)$, but resistance to ceftriaxone and streptomycin was only $44.4 \%$.
Pasteurella spp. showed a wide range of resistance to ampicillin (100\%); tetracycline and streptomycin $(85.7 \%)$; and ceftriaxone, chloramphenicol, doxycycline, and trimethoprim-sulfamethoxazole $(71.4 \%)$; but only $57.1 \%$ to gentamycin. Finally, Listeria spp. exhibited complete resistance to both ampicillin and doxycycline $(100 \%)$, followed by 
Table-4: Prevalence of Escherichia coli and Salmonella serotypes from examined samples.

\begin{tabular}{|c|c|c|c|}
\hline Samples & Organs & $\begin{array}{l}\text { Escherichia coli Serotypes } \\
(\text { No }=36)\end{array}$ & $\begin{array}{l}\text { Salmonella serovars } \\
(\text { No }=32)\end{array}$ \\
\hline Live disease & Vaginal swabs & $\begin{array}{c}2(0125), 2(0111) \\
2(0114) \\
2(0142)\end{array}$ & $\begin{array}{l}\text { (4) S. Enteritidis } \\
\text { (2) S. Suberu } \\
\text { (2) S. Elisabeth ville }\end{array}$ \\
\hline \multirow[t]{3}{*}{ Freshly dead } & Uterine secretions & $4(0125)$ & $\begin{array}{l}\text { (2) S. Enteritidis } \\
\text { (2) S. Typhimurium } \\
\text { (2) S. Give } \\
\text { (2) S. Stuttgart }\end{array}$ \\
\hline & Liver & $\begin{array}{c}10(0125) \\
2(0167), 2(0152)\end{array}$ & $\begin{array}{l}\text { (2) S. Enteritidis } \\
\text { (2) S. Typhimurium } \\
\text { (2) S. London }\end{array}$ \\
\hline & Intestine & $4(0125)$ & (2) S. Stuttgart \\
\hline Aborted fetus & Fetus & $4(0125), 2$ (0119) & $\begin{array}{l}\text { (4) S. Enteritidis } \\
\text { (2) S. Derby } \\
\text { (2) S. Give }\end{array}$ \\
\hline
\end{tabular}

tetracycline (66.7\%) and ciprofloxacin (50\%), while the percentage of resistance was $33.3 \%$ to norfloxacin, chloramphenicol, and streptomycin.

\section{PCR results}

All the isolated strains underwent confirmation by screening for common genes using conventional PCR: phoA for E. coli, invA for Salmonella, clfA for $S$. aureus, and a variety of genes for the Pasteurellaceae family ( $k m t 1$ for P. multocida, ssn for Mannheimia, and $16 \mathrm{~S}$ and 23S RNA for Gallibacterium), and $16 \mathrm{~S}$ RNA for L. monocytogenes.

We used conventional PCR techniques with specific primers to detect virulence genes in $E$. coli, Salmonella, S. aureus, and L. monocytogenes. The genes were selected if they occurred at a high frequency in the bacteria. The results showed that the E. coli strains incorporated the serum resistant gene (iss) but lacked the shiga toxin (stx) gene. All Salmonella strains carried the enterotoxin gene stn, invasion genes invA and $a v r A$, and the outer membrane protein gene $o m p F$, but the SopE gene was only present in $31.25 \%$ of isolates. However, the hemolysin gene ( $h l y)$ was found in $66.7 \%$ of $S$. aureus strains and the hemolysin gene $(h l g)$ in $33.3 \%$ of Listeria spp. strains (Table-6).

The genotypic detection for antimicrobial resistance genes was performed for E. coli and Salmonella strains because these isolates were present in a high percentage of the isolates (34\% and $30.2 \%$, respectively) and showed different phenotypic patterns of antimicrobial resistance according to the presence of the selected screening genes Figure-1. The E. coli strains harbored genes against many groups of antimicrobial agents such as tetracycline (tetA $(A)$ gene, $100 \%)$, streptomycin (aad1 gene, 94.4\%, 34/36), and $\beta$ lactamase (bla TEM gene, $66.7 \%, 24 / 36$, but lacked the quinolone resistance gene $(q n r S)$ although a percentage resistance to quinolone was phenotypically observed. All Salmonella strains had the quinolone-resistant gene (qac) but a low percentage of quinolone resistance phenotypically.

\section{Discussion}

In general, rabbit farms are considered the fastest growing industry for their income, which is derived

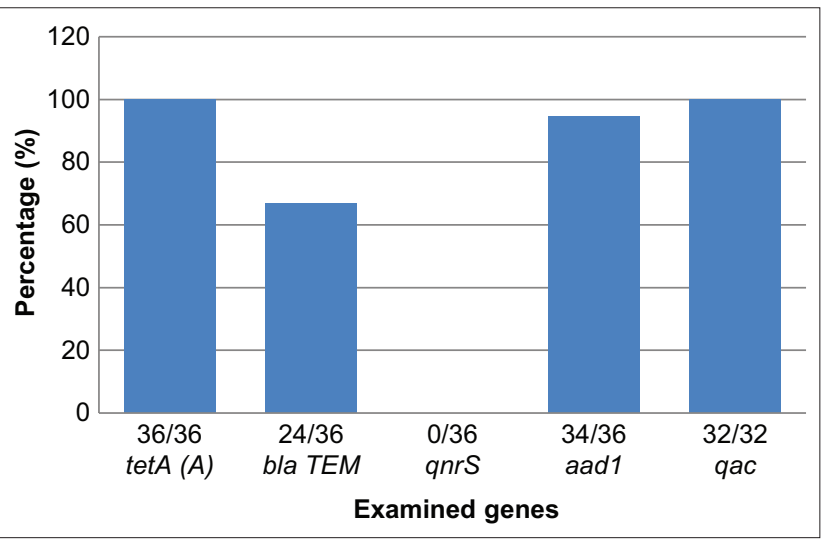

Figure-1: Results for antimicrobial resistant genes of Escherichia coli and Salmonella by polymerase chain reaction technique.

from meat, fur, or the use of rabbits as experimental animals for laboratory trials. Thus, it is crucial to determine important rabbit diseases to avoid economic loss and zoonotic threats [40]. For this reason, we focused on cases of aborted female does because reproductive females are the most important link in the production chain and recorded the bacterial pathogens present in different organs. We collected 106 samples from aborted does, which identified E coli, Salmonella spp., S. aureus, Pasteurella spp., and Listeria spp. in percentage of $36(34 \%), 32(30.2 \%), 18(16.9 \%), 14$ (13.2\%), and $12(11.3 \%)$ samples, respectively. Pisoni et al. [41] categorized the most frequent lesions in rabbits as affecting the gastroenteric organs, followed by the genitourinary, respiratory, and cutaneous organs. In addition, the presence of $E$. coli was $29.8 \%$, S. aureus was $9.3 \%$, and P. multocida was $7.9 \%$ in rabbit breeding facilities [41].

Colibacillosis is a common disease in rabbits, is a major infectious disease threat to the rabbit breeding industry [4]. E. coli was identified as the most prevalent species among bacterial organisms that causing enteritis and mortality in rabbits [42]. Enteropathogenic E. coli is the only known class of E. coli in rabbits that induces acute intestinal pathology marked by inflammatory lesions of the gut [43]. 


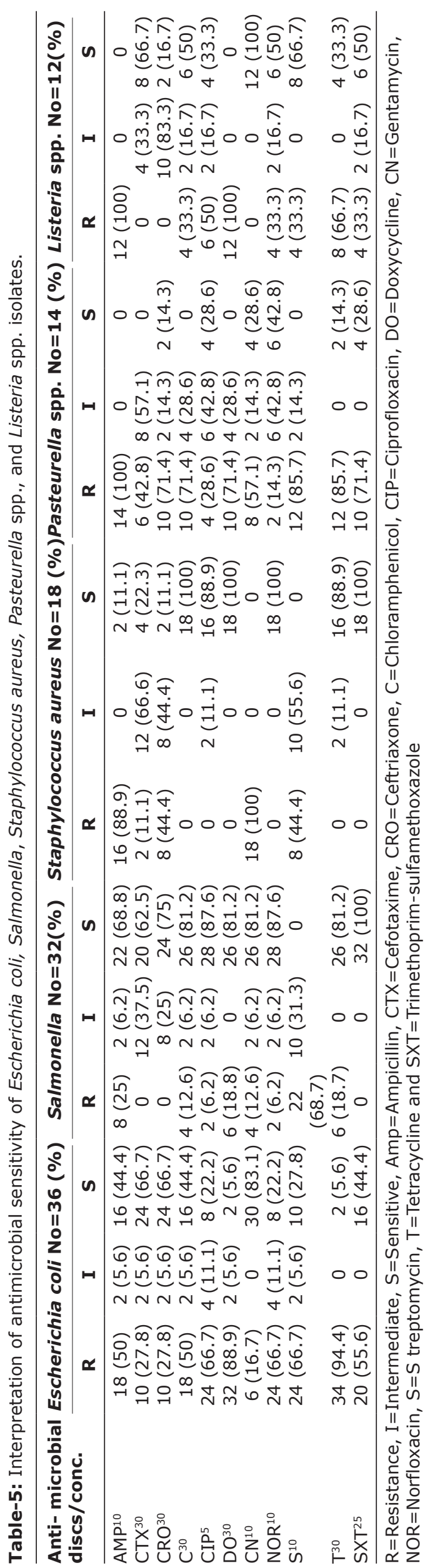

Table-6: Polymerase chain reaction results for the examined virulence genes for different bacterial culture.

\begin{tabular}{llc}
\hline Organism & Examined Genes & Positive/Total (\%) \\
\hline Escherichia coli & Iss & $36 / 36(100 \%)$ \\
& St $\times 1$ & $0 / 36(0 \%)$ \\
Salmonella & stn & $32 / 32(100 \%)$ \\
& invA & $32 / 32(100 \%)$ \\
& avrA & $32 / 32(100 \%)$ \\
& ompf & $32 / 32(100 \%)$ \\
& sopE & $10 / 32(31.25 \%)$ \\
S. aureus & hly & $12 / 18(66.7 \%)$ \\
Listeria spp. & hlg & $4 / 12(33.3 \%)$ \\
\hline
\end{tabular}

Our study isolated E. coli in 36 of 106 (34\%) samples as a single or combined infection. The $E$. coli serotypes were confirmed as $\mathrm{O} 125, \mathrm{O} 111, \mathrm{O} 114, \mathrm{O} 142$, O167, O152, and O119, which, with the exception of O119, did not correlate with those of Hamed et al. [42], who confirmed E. coli serotypes O126, O128, O125, and O119 from diseased rabbits. Another study reported E. coli serotypes O55, O128, O126, O119, O78, O44, O111, O114, O26, O75, O103, O145, and $\mathrm{O} 158$ as frequently isolated from infected rabbits [44]. In Egypt, the higher isolation percentage of $E$. coli from rabbits was reported by Eid et al. [43] (525 of 625, 84\%) that belonged to serotypes O153, O125, O27, and O158. Collectively, these findings indicate that a wide range of $E$. coli serotypes in rabbits may cause disease conditions.

Virulent pathogenic bacteria have more tools and abilities to increase their systemic action, escaping from the host's immune system and withstanding the bactericidal effect of the antimicrobial drugs. Combinations of the virulence and antibiotic resistance genes result in new and uncontrollable bacterial strains with higher morbidity and mortality rates than the original bacteria. Thus, we attempted to identify genes suspected of increasing bacterial virulence. First, we did not detect there was no shiga toxin (stx) in any of the E. coli isolates, but the iss was gene detected in all E. coli isolates. This result was similar to that reported by Eid et al. [43], who examined different isolates of E. coli, none of which were positive for $s t x 1$ or $s t x 2$. Other authors $[45,46]$ discussed the presence of shiga toxin, which is encoded by genes, and mentioned its ability to attach the intestinal epithelial cells and causing diarrhea.

Salmonellosis is an unusual cause of acute enteritis in rabbits, which is characterized by rapid death and infertility, while pregnant does commonly abort [42]. The samples from does with aborted fetuses in this study showed different Salmonella serovars in 32 of 106) (30.2\%) samples, including $S$. Enteritidis, $S$. Typhimurium, $S$. Give, $S$. London, $S$. Derby, $S$. Elisabethville, $S$. Suberu, and $S$. Stuttgart. Pisoni et al. [42] also recorded a variety of Salmonella serovars from weaning rabbits, including $S$. Enteritidis, $S$. Mbadaka, $S$. Heidelburg, $S$. Typhimurium and S. Pullorum. 
$S$. Enteritidis was the most isolated serovar in our study (12/32), but $S$. Typhimurium was also isolated (4/32). This finding contradicts those of Iman and Lamia [47], who mentioned that the most detected strain from vaginal swabs from aborted cases was $S$. Typhimurium (10/135, 7.40\%). Therefore, no clear relationship between specific Salmonella serovars was identified as associated with induced abortion.

The virulence properties of Salmonella strains were assessed by the presence of different virulence genes, such as invA, stn, avrA, and omp E, which were present in all examined Salmonella strains. However, the sopE gene was only detected in $31.25 \%$ of the Salmonella strains. The function of invA (Salmonella invasion protein gene) is the attachment of the pathogen to the host in addition to phoA, SopE, and avrA) [27]. The enterotoxin (stn) gene was demonstrated as a suitable PCR target for the detection of Salmonella strains with most potent biological poisons [48]. Undoubtedly, all isolated Salmonella strains in our study carried virulent genes to help in attaching and invading all of the rabbits' body systems.

$S$. aureus was isolated from intrauterine metritis rabbits of a dead pregnant female [49]. S. aureus is a dangerous pathogen, secreting a number of toxins and hemolysins that cause tissue damage [50]. In a sample of 106 rabbits from nine rabbit farms, 18 (16.9\%) $S$. aureus strains were detected, of which 12 (66.7\%) harbored the hemolysin gene [51]. After studying the mortality rates of these nine rabbit farms, it was suggested that $S$. aureus was an important pathogen causing the death of rabbits on these rabbit farms. In general, $S$. aureus has a combination of virulence factors, which were thought to contribute to the pathogenicity. The presence of virulence genes in $S$. aureus isolates was screened by PCR assays using primers previously reported, including those for hemolysin (hla and hlb). This study highlighted the importance of $S$. aureus in infection or coinfection results in cases of early embryonic death, especially with the high prevalence of this virulence gene.

Pasteurella is a normal inhabitant of the upper respiratory tract in a variety of animal species, including rabbits. However, many factors can convert it into a pathogenic form leading to death [52]. In the present study, there were 14 of 106 (13.2\%) Pasteurella spp. identified as $P$. multocida by morphologic, microscopical, and biochemical characteristics from samples of aborted fetus, followed by liver and then uterine secretions. Identification was confirmed by PCR using three different genes, which identified 12 of the 14 strains as Gallibacterium spp.

$P$. multocida was isolated and confirmed from liver samples by Asran et al. [53]. PCR represents a suitable tool for genetic characterization of rabbit Pasteurellaceae isolates while the biochemical analysis showed high heterogeneity and in some cases provided unclear results [54]. Gallibacterium is a commensal of the upper respiratory tract and the lower genital tract of chickens [55] and in non-avian hosts, including cattle, horse, pigs, sheep, and rabbits [56]. As observed in this study, Gallibacterium spp. is also present in aborted rabbits, although its role in the rabbit industry required further investigation.

Listeriosis in rabbits is considered as one of the major disease problems facing rabbit health and breeding in the form of infertility, abortion, or myometrial contraction and high mortality resulting in severe economic losses in rabbit farms [57]. In our study, 12 (11.3\%) Listeria spp. were identified, but only four strains were L. monocytogenes, which were present in samples of aborted fetuses and vaginal swabs. A higher incidence of $L$. monocytogenes was reported by Hatab and El-Latif [58], with a percentage of 30\% and $20 \%$ from aborted dead and aborted live does, respectively. However, the incidence of L. monocytogenes was reported as $21.73 \%$ and $31.66 \%$ from aborted does and dead fetuses, respectively, as mentioned by Moursi et al. [57] during an examination of rabbit farms in Ismailia of rabbits suffering from encephalitis and abortion.

Because most of the isolated strains in our study were Salmonella and E. coli, it prompted us to seek suitable treatment methods and acquired resistance genes, especially after detection of the virulence pattern of bacterial species such as Salmonella, E. coli, S. aureus, and L. monocytogenes.

Antimicrobial resistance is a concern in human and veterinary medicines as being implicated in the failure of treatment protocols. Therefore, the proper determination of the resistance patterns represents a prerequisite for adapting successful control measures [59]. In this study, all the isolated strains related to different bacterial species were examined using the disk-diffusion method with different antimicrobials. A wide range of antimicrobial resistance was noted. A high resistance pattern in $E$. coli isolates was noted against tetracycline, doxycycline, and trimethoprim-sulfamethoxazole $(94.4 \%, 88.9 \%$, and $55.6 \%$, respectively), and the representative gene for tet $A$ was present in all strains of $E$. coli. However, the prevalence of resistance against norfloxacin and ciprofloxacin was $66.7 \%$, but the genes regulating quinolone resistance (qnrs) were absent in all E. coli strains. Furthermore, the aadl gene was detected in $94.4 \%$ of isolates, but only $66.7 \%$ showed phenotypic resistance to streptomycin. The resistance gene bla Tem was present in $66.7 \%$, and the lowest phenotypic resistance percentage was $50 \%$ for ampicillin and chloramphenicol. Furthermore, Zhao et al. [4] reported resistance rates of $55 \mathrm{E}$. coli strains against tetracycline and ampicillin as $78.2 \%$ and $65.5 \%$, respectively. Landoni and Albarellos [60] mentioned that the wide range of antimicrobial agents, such as $\beta$-lactams (penicillins and cephalosporin), aminoglycosides, tetracycline, sulfonamides, and fluoroquinolones was used in Colibacillosis treatment. The 
mechanism of tetracycline resistance was mediated through the efflux pump and encoded for a group of genes (tet $A, \operatorname{tet} B, \operatorname{tet} C, \operatorname{tet} D, \operatorname{tet} E$, and tet $G)$ [61]. The difference in phenotypic and genotypic results revealed that genotypic detection is not the best indicator of resistance.

Salmonella revealed high resistance only for streptomycin (68.7\%) and low resistance to tetracycline and quinolones, although the quinolone-resistant gene ( $q a c$ ) was present in all examined Salmonella strains. Gram-negative bacteria were reported as most frequently found in combination with genes coding for resistance to aminoglycosides, chloramphenicol, sulfonamides, trimethoprim, and $\beta$-lactams [62]. In contrast, Iman and Lamia [47] reported that rabbit is a potential reservoir for salmonellosis and the common Salmonella serotype was $S$. Typhimurium DT10 with multi-resistant phenomena emergent in the circulating Salmonella strains from rabbit sources. In addition, animal breeding could represent a possible reservoir of antibiotic resistance and virulent bacteria, as observed in rabbits [63].

S. aureus is pathogenic and can develop antibiotic resistance, resulting in high morbidity and mortality [51]. In the present study, the isolated $S$. aureus strains showed high resistance for gentamycin $(100 \%)$ and ampicillin (88.9\%) but only $44.4 \%$ resistance for ceftriaxone and streptomycin and were highly sensitive to ciprofloxacin and trimethoprim and sulfamethoxazole. Hamed and Youssef [64] found that all S. aureus strains isolated from rabbits in Egypt were multidrug-resistant to trimethoprim and sulfamethoxazole, and gentamicin and ampicillin, and all strains were sensitive to ciprofloxacin. This finding showed the different pattern of the bacteria toward antimicrobial resistance.

Our study revealed a wide range of the resistance of Pasteurella spp. as ampicillin (100\%); tetracycline and streptomycin (85.7\%); ceftriaxone, chloramphenicol, doxycycline and trimethoprim-sulfamethoxazole $(71.4 \%)$; and gentamycin $(57.1 \%)$. In contrast, Wang et al. [65] revealed streptomycin, gentamycin, and ceftriaxone with resistance rates of $27.80 \%$, $15.61 \%$, and $2.44 \%$, respectively. Furthermore, Mohamed et al. [66] stated that Pasteurella spp. only showed resistance against streptomycin and a wide range of antibiotic susceptibility for norfloxacin, ciprofloxacin, doxycycline, and gentamycin.

Listeria spp. showed resistance to ampicillin and doxycycline $(100 \%)$, tetracycline $(66.7 \%)$, and ciprofloxacin $(50 \%)$, but only $33.3 \%$ resistance to norfloxacin, chloramphenicol, and streptomycin. Hamed et al. [42] reported that the treatment with gentamicin and ofloxacin showed progressive cure for experimentally infected rabbits with an L. monocytogenes strain sensitive to ofloxacin, erythromycin, gentamicin, norfloxacin, and ciprofloxacin. Furthermore, Moursi et al. [57] reported that L. monocytogenes was highly sensitive to ampicillin, tetracycline, doxycycline, trimethoprim, and gentamycin and moderately sensitive to ciprofloxacin and chloramphenicol but resistant to streptomycin and cefotaxime.

\section{Conclusion}

Our study illustrates that Salmonella is a common pathogen as a single cause of early embryonic death, followed by E. coli, S. aureus, Pasteurella, and Listeria, respectively. On the other hand, other cases showed mixed pathogens that were considered the cause of abortion and consisted of combined infection with two, three, or four bacteria, mostly with Salmonella or and E. coli, while 24 samples were negative for bacterial isolation. Further investigation is necessary to identify the main cause of early embryonic death and to confirm our results, which suggest that the different etiological agent(s) were incorporated and may play a role in the initiation of abortion in does.

\section{Authors' Contributions}

HB, HR, and AGS designed the study. HB, HR, AGS, and AAEM performed the research and drafted the manuscript. HB and AGS analyzed the data. HB and AGS revised and finalized the manuscript for submission. All authors read and approved the final manuscript.

\section{Acknowledgments}

The authors would like to thank the Reference Laboratory for Veterinary Quality Control on Poultry Production, Egypt, for providing the infrastructure for conducting the study. The authors did not receive any funds for this study.

\section{Competing Interests}

The authors declare that they have no competing interests.

\section{Publisher's Note}

Veterinary World remains neutral with regard to jurisdictional claims in published institutional affiliation.

\section{References}

1. Khan, K.S., Khan, R., Khan, A., Sultan, N.A.K. and Ahmad, N. (2016) Growth performance and meat quality of rabbits under different feeding regimes. Trop. Anim. Health Prod., 48(8): 1661-1666.

2. Michelland, R.J., Combes, S. and Monteils, V. (2010) Molecular analysis of the bacterial community in digestive tract of rabbit. Anaerobe, 16(2): 61-65.

3. Caliskan, C., Ozalp, R.G., Ozyigit, M.O.M. and Seyrek, I.K. (2007) Foetal mummification and necrotic metritis in a New Zealand white rabbit (Oryctolagus cuniculus). Aust. Vet. Pract., 37(4): 134-136.

4. Zhao, X., Yang, J., Ju Z., Chang, W. and Sun, S. (2018) Molecular characterization of antimicrobial resistance in Escherichia coli from rabbit farms in Tai'an, China. Biomed. Res. Int., 2018: 8607647.

5. Sarowska, J., Koloch, B.F., Kmiecik, A.J., Madrzak, M.F., Ksiazczyk, M., Bugla-Ploskonska, G. and Krol, I.C. (2019) Virulence factors, prevalence and potential transmission of extraintestinal pathogenic Escherichia coli isolated from 
different sources: Recent reports. Gut Pathog., 11: 10.

6. Patton, N.M., Hagen, K.W., Gorham, J.R. and Flatt, R.E. (2008) Domestic Rabbits: Diseases and Parasites. A Pacific Northwest Extension Publication Oregon Idaho Washington. Archival Copy. For Current Information, See the OSU Extension Catalog. Oregon State University Available from: https://www.catalog.extension.oregonstate. edu. Retrieved on 10-04-2021.

7. Abd El Gwad, A.M., Abd El Rahman, A.A. and Ali, M.M. (2004) Significance of Staphylococcus aureus in rabbits in Assiut governorate. Assiut Univ. Bull. Environ. Res., 7(1): 77-84.

8. Awad, N.F.S. (2013) Some Studies on Rabbit Pasteurellosis [Ph. D., Thesis]. Zagazig University, Zagazig, Egypt.

9. Schwarz, S., Shen, J., Kadlec, K., Wang, Y., Michael, G.B., Febler, A.T. and Vester, B. (2016) Lincosamides, streptogramins, phenicols, and pleuromutilins: Mode of action and mechanisms of resistance. Cold Spring Harb. Perspect. Med., 6 (11): 1-30.

10. Abdelgader, S.A., Shi, D., Chen, M., Zhang, L., Hejair, H.M.A., Muhammad, U., Yao, H. and Zhang, W. (2018) Antibiotics resistance genes screening and comparative genomics analysis of commensal Escherichia coli isolated from poultry farms between China and Sudan. Biomed. Res. Int., 2018: 5327450.

11. Lee, M.D. and Nolan, K.L. (2008) A laboratory manual for the isolation and identification of avian pathogen, colibacillosis. In: Zavala, L.D., Swayne, D.E., Glisson, J.R., Jackwood, M.W., Pearson, J.E. and Reed, W.M., editors. Editorial Board for the American Association of Avian Pathologists. $5^{\text {th }}$ ed., 978-0-9789163-2-9 Ch. 3. Athens, GA, USA. p10-16.

12. International Organization for Standardization ISO 6579 Part 1. (2017) Microbiology of the Food Chain Horizontal Method for the Detection, Enumeration and Serotyping of Salmonella-Part 1: Detection of Salmonella spp. International Standards Organization, Geneva.

13. International Organization for Standardization ISO 6579 Part 3. (2014) Microbiology of Food and Animal Feeding Stuffs-Horizontal Method for the Detection of Salmonella. International Standards Organization, Geneva.

14. Grimont, P.A.D. and Weill, F.X. (2007) Antigenic Formulas of the Salmonella Serovars. $9^{\text {th }}$ ed. WHO Collaborating Center for Reference and Research on Salmonella, Paris.

15. Bacteriological Analytical Manual "BAM" Food and Drug Administration. (2001) In: Bennett, R.W. and Lancette, G.A., editors. Staphylococcus aureus. $8^{\text {th }}$ ed., Ch. 12. FDA, USA.

16. International Organization for Standardization ISO (68881: 1999 AMD2 2018). (2018) Microbiology of Food and Animal Feeding Stuffs-Horizontal Method for Enumeration of Coagulase-Positive staphylococci (Staphylococcus aureus and Other Species). International Organization for Standardization, Geneva.

17. Glisson, J.R., Sandhu, T.S. and Hofacre, C.L. (2008) Pasteurellosis, avibacteriosis, gallibacteriosis, riemerellosis and pseudotuberculosis. In: Dufour-Zavala, L., editor. A Laboratory Manual for the Isolation, Identification and Characterization of Avian Pathogens. $5^{\text {th }}$ ed. American Association of Avian Pathologists, Georgia. p12-18.

18. International Organization for Standardization ISO 11290 Part 1. (2017) Horizontal Methods for the Detection of Listeria monocytogenes. $2^{\text {nd }}$ ed. International Organization for Standardization, Geneva.

19. Centers for Disease Control and Prevention and World Health Organization (CDC and WHO). (2003) In: Mindy, J. and Perilla, M.P.H., editors. Manual for the Laboratory Identification and Antimicrobial Susceptibility Testing of Bacterial Pathogens of Public Health Importance in the Developing World. World Health Organization, Atlanta, Georgia, United States.

20. Clinical and Laboratory Standards Institute. (2017)
Performance standards for antimicrobial susceptibility testing. In: $27^{\text {th }}$ Informational Supplement Document M100-S27. Vol. 37. CLSI, Wayne.

21. Hu, Q., Tu, J., Han, X., Zhu, Y., Ding, C. and Yu, S. (2011) Development of multiplex PCR assay for rapid detection of Riemerella anatipestifer, Escherichia coli, and Salmonella enterica simultaneously from ducks. J. Microbiol. Methods, 87(1): 64-69.

22. Yaguchi, K., Ogitani, T., Osawa, R., Kawano, M., Kokumai, N., Kaneshige, T., Noro, T., Masubuchi, K. and Shimizu, Y. (2007) Virulence factors of avian pathogenic Escherichia coli strains isolated from chickens with colisepticemia in Japan. Avian Dis., 51(3): 656-662.

23. Dipineto, L., Santaniello, A., Fontanella, M., Lagos, K., Fioretti, A. and Menna, L.F. (2006) Presence of Shiga toxin-producing Escherichia coli O157: H7 in living layer hens. Lett. Appl. Microbiol., 43(3): 293-295.

24. Randall, L.P., Cooles, S.W., Osborn, M.K.., Piddock, L.J.V. and Woodward, M.J. (2004) Antibiotic resistance genes, integrons and multiple antibiotic resistance in thirty-five serotypes of Salmonella enterica isolated from humans and animals in the UK. J. Antimicrob. Chemother., 53(2): 208-216.

25. Colom, K., Pèrez, J.A.R., Fernández, A., Lariňo, E. and Cisterna, R. (2003) Simple and reliable multiplex PCR assay for detection of $\mathrm{bla}_{\mathrm{TEM}}$, bla $\mathrm{SHV}_{\mathrm{SH}}$ and bla $\mathrm{OXX}_{\mathrm{O}-1}$ genes in Enterobacteriaceae. FEMS Microbiol. Lett., 223(2): $147-151$.

26. Robicsek, A., Strahilevitz, J., Sahm, D.F., Jacoby, G.A. and Hooper, D.C. (2006) qnr prevalence in ceftazidime-resistant Enterobacteriaceae isolates from the United States. Antimicrob. Agents Chemother., 50(8): 2872-2874.

27. Salem, W.M., Shibat El-Hamed, D.M.W., Sayed, W.F. and Elamary, R.B. (2017) Alterations in virulence and antibiotic-resistant genes of multidrug-resistant Salmonella serovars isolated from poultry: The bactericidal efficacy of Allium sativum. Microb. Pathog., 108: 91-100.

28. Thung, T.Y., Radu, S., Mahyudin, N.A., Rukayadi, Y., Zakaria, Z., Mazlan, N., Tan, B.H., Lee, E., Yeoh, S.L., Chin, Y.Z., Tan, C.W., Kuan, C.H., Basri, D.F. and Wan Mohamed Radzi, C.W.J. (2018) Prevalence, virulence genes and antimicrobial resistance profiles of Salmonella serovars from retail beef in Selangor, Malaysia. Front. Microbiol., $8: 2697$.

29. Huehn, S., La Ragione, R.M., Anjum, M., Saunders, M., Woodward, M.J., Bunge, C., Helmuth, R., Hauser, E., Guerra, B., Beutlich, J., Brisabois, A., Peters, T., Svensson,L., Madajczak, G., Litrup, E., Imre, A., HerreraLeon, S., Mevius, D., Newell, D.G. and Malorny, B. (2010) Virulotyping and antimicrobial resistance typing of Salmonella enterica serovars relevant to human health in Europe. Foodborne Pathog. Dis., 7(5): 523-535.

30. Tatavarthy, A. and Cannons, A. (2010) Real-time PCR detection of Salmonella species using a novel target: The outer membrane Porin $\mathrm{F}$ gene (ompF). Lett. Appl. Microbiol., 50(6): 645-652.

31. Chuanchuen, R., Khemtong, S. and Padungtod, P. (2007) Occurrence of qacE/qacEDeltal genes and their correlation with class 1 integrons in Salmonella enterica isolates from poultry and swine. Southeast Asian J. Trop. Med. Public Health, 38(5): 855-862.

32. Badr, H., Abdel Rahman, M.A.A., Farghaly, E.M., Gaber, A., Roshdy, H. and Nasef, S.A. (2015) Characterization of some aerobic bacterial microorganisms isolated from newly hatched imported ducklings, Egypt. Poult. Sci., 35(4): 1123-1136.

33. Fei, W., Hongjun, Y., Hong-Bin, H., Changfa, W., Yundong, G., Qifeng, Z., Wiaohong, W. and Yanjun, Z. (2011) Study on the hemolysin phenotype and the genotype distribution of Staphylococcus aureus caused bovine mastitis in Shandong dairy farms. Int. J. Appl. Res. Vet. Med., 9(4): 416-421. 
34. Erfan, A.M. and Marouf, S. (2019) Cinnamon oil downregulates virulence genes of poultry respiratory bacterial agents and revealed significant bacterial inhibition: An in vitro perspective. Vet. World, 12(11): 1707-1715.

35. Hawari, A.D., Hassaw, D.S. and Sweiss, M. (2008) Isolation and identification of Mannheimia haemolytica and Pasteurella multocida in sheep and goats using biochemical tests and random amplified polymorphic DNA (RAPD) analysis. J. Biol. Sci., 8(7): 1251-1254.

36. Bojesen, A.M., Vazquez, M.E., Robles, F., Gonzalez, C., Soriano, E.V., Olsen, J.E. and Christensen, H. (2007) Specific identification of Gallibacterium by a PCR using primers targeting the $16 \mathrm{~S}$ rRNA and $23 S$ rRNA genes. Vet. Microbiol., 123(1-3): 262-268.

37. Kumar, A., Grover, S. and Batish, V.K. (2015) Exploring specific primers targeted against different genes for a multiplex PCR for detection of Listeria monocytogenes. 3 Biotech, 5(3): 261-269.

38. Mohammed, T.K. (2019) Detection of hly A gene in Listeria monocytogenes isolated from cerebral spinal fluid of some Iraqi meningitis. J. Pharm. Sci. Res., 11(2): 614-617.

39. Sambrook, J., Fritscgh, E.F. and Mentiates, T. (1989) Molecular Cloning. A Laboratory Manual. Vol. 3. Laboratory Press, Cold Spring Harbor, New York. p55-57.

40. Chavhan, S.G., Jangir, B.L, Kurkure, N.V. and Chopade, N.A. (2011) Infectious Diseases of Rabbits. p1-7. Available from: https://www.researchgate.net/publication/252055448. Retrieved on 09-04-2021.

41. Pisoni, A.M., Poloni, R., Tosi, R., Gallazzi, D. and Grilli, G. (2008) Isolation and antimicrobial susceptibility of bacterial pathogens of the rabbit. World Rabbit Sci., 16: 111-120.

42. Hamed, A.M., Eid, A.A.M. and El-Bakrey, R.M.M. (2013) A review of rabbit diseases in Egypt. Wartazoa, 23(4): 185-194.

43. Eid, H.M., Nahla, T.A. and Eman, M.Z. (2017) Bacteriological studies on Escherichia coli infection in rabbits. Suez Canal Vet. Med. J., 22(2): 133-144.

44. Shahin, A.M., Lebdah, M.A. and Ali, G.R.M. (2011) Escherichia coli as an etiological agent of mucoid enteropathy in rabbits. Researcher, 3(7): 8-16.

45. Hussein, A.M. and Yousif, A.A. (2015) Detection of stx1 and stx2 virulence genes from Escherichia coli O157: H7 isolated from calves by PCR assay. Int. J. Adv. Res. Biol. Sci., 2(11): 324-329.

46. Yousif, A.A. and Hussein, M.A. (2015) Prevalence and molecular detection of intimin (eaeA) virulence gene in E. coli O157: $\mathrm{H} 7$ in calves. Res. J. Vet. Pract., 3(3): 47-51.

47. Iman, I.A.S. and Lamia, M.R. (2015) Isolation and identification of Salmonella enterica Typhimurium from rabbits. Egypt. J. Rabbit Sci., 25(2): 137-148.

48. Prager, R., Fruth, A. and Tschäpe, H. (1995) Salmonella enterotoxin (stn) gene is prevalent among strains of Salmonella enterica but not among Salmonella Bongori and other Enterobacteriaceae. FEMS Immunol. Med. Microbiol., 12(1): 47-50.

49. Abd El Motelib, T.Y. and Salem, B. (1991) Staphylococcal mastitis in domestic rabbits. Assiut Vet. Med. J., 25(49): 241-249

50. Ivyakolu, S., Chikkala, R., Ratnakar, K.S. and Sritharan, V. (2019) Hemolysins of Staphylococcus aureus an update on their biology, role in pathogenesis and as targets for anti-virulence therapy. Adv. Infect. Dis., 9(2): 80-104.

51. Wang, J., Sang, L., Sun, S., Chen, Y., Chen, D. and Xie, X. (2019b) Characterisation of Staphylococcus aureus isolated from rabbits in Fujian, China. Epidemiol. Infect., 147(e256): $1-5$.

52. Carrillo, M.P., Martinez, N.M., Patiño, M.D.P. and Iregui, C.A. (2015) Inhibition of Pasteurella multocida adhesion to rabbit respiratory epithelium using lectins. Vet. Med. Int., 2015: 365428.

53. Asran, E.A., Khalil, S.A. and Hegazy, A.M. (2016) Identification and molecular analysis of Pasteurella Multocida isolated from rabbits. Alex. J. Vet. Sci., 48(1): 34-41.

54. Ahmed, S., Abdel-Salam, M.S., Hafez, S.S. and Nemr, W. (2016) Molecular characterization of Pasteurella multocida isolated from rabbit in Egypt. Am. J. Biochem. Mol. Biol., 6(2): 53-59.

55. Singh, S.V., Singh, B.R., Sinha, D.K., Vinodh, K.O.R., Prasanna, V.A., Bhardwaj, M. and Dubey, S. (2016) Gallibacterium anatis: An emerging pathogen of poultry birds and domiciled birds. J. Vet. Sci. Technol., 7(3): 324-331.

56. Krishnegowdaa, D.N., Dhamaa, K., Mariappana, A.K., Munuswamya, P., Yatoob, M.I., Tiwaric, R., Karthikd, K., Bhatte, P. and Reddya, M.R. (2020) Etiology, epidemiology, pathology, and advances in diagnosis, vaccine development, and treatment of Gallibacterium anatis infection in poultry: A review. Vet. Q., 40(1): 16-34.

57. Moursi, M.K., El-Genaidy, H.M., Sabah, K.H. and Yousseff, F.M. (2006) Listeria infection in rabbits at Ismailia province. SCVMJ, 10(1): 203-221.

58. Hatab, M.E. and Abd El-Latif, M.M. (2006) Studies on some bacterial associated with abortion in rabbits. Assiut. Vet. Med. J., 52(109): 285-293.

59. Eid, S., Marouf, S., Hefny, H.Y. and Al-Atfeehy, N.M. (2019) Pasteurellaceae members with similar morphological patterns associated with respiratory manifestations in ducks. Vet. World, 12(12): 2061-2069.

60. Landoni, M.F. and Albarellos, G. (2015) The use of antimicrobial agents in broiler chickens. Vet. J., 205(1): 21-27.

61. Shin, S.W., Shin, M.K., Jung, M., Belaynehe, K.M. and Yoo, H.S. (2015) Prevalence of antimicrobial resistance and transfer of tetracycline resistance genes in Escherichia coli isolates from beef cattle. Appl. Environ. Microbiol., 81(16): 5560-5566.

62. Zhao, W.H., Chen, G., Ito R., Kimura, S. and Hu, Z.Q. (2012) Identification of a plasmid-borne blaIMP-11 gene in clinical isolates of Escherichia coli and Klebsiella pneumoniae. J. Med. Microbiol., 61(2): 246-251.

63. Lauková, A., Strompfová, V., Szabóová, R., Bónai, A., Matics, Z., Kovács, M. and Pogány, S.M. (2019) Enterococci from Pannon white rabbits: Detection, identification, biofilm and screening for virulence factors. World Rabbit Sci., 27(1): 31-39.

64. Hamed, D.M. and Youssef, A.I. (2013) Clinical features of methicillin-resistant Staphylococcus aureus (MRSA) infection in rabbits and its zoonotic potentials. Pak. J. Nutr., 12(3): 244-249.

65. Wang, J., Sang, L., Sun, S., Chen, Y., Chen, D. and Xie, X. (2019a) Characterization of Pasteurella multocida isolated from dead rabbits with respiratory disease in Fujian, China. BMC Vet. Res., 15(1): 438.

66. Mohamed, F.M., Mansy, M.F., Abd-Al-Jwad, A.M. and Hassan, A.K. (2020) Antibacterial sensitivity and detection of virulence-associated gene of Pasteurella multocida isolated from Rabbits. J. World Poult. Res., 10(2S): 165-171. 